\title{
A new species of Arcupbantes from the Russian Far East, with notes on the genera Fuscipbantes and Bifurcia (Arachnida: Aranei: Linyphiidae)
}

\section{Новый вид рода Arcuphantes с Российского Аальнего Востока, с заметками о родах Fuscipbantes и Bifurcia (Arachnida: Aranei: Linyphiidae)}

\author{
Andrei V. Tanasevitch \\ A.B. Танасевич \\ Centre for Forest Ecology and Production, Russian Academy of Sciences, Profsoyuznaya Str. 84/32, Moscow 117997 Russia. \\ E-mail: and-tan@mail.ru. \\ Центр по проблемам экологии и продуктивности лесов РАН, Профсоюзная ул. 84/32, Москва 117997 Россия.
}

KEY WORDS: Spiders, Micronetinae, Arcuphantes, Fusciphantes, Bifurcia, new species, Russian Far East.

КЛЮЧЕВЫЕ СЛОВА: Пауки, Micronetinae, Arcuphantes, Fusciphantes, Bifurcia, новый вид, Российский Дальний Восток.

ABSTRACT. Arcuphantes maritimus sp.n. is diagnosed and described from the Maritime Province, the Russian Far East. The new species can be distinguished from other species of the genus by peculiar shape of the paracymbium and the pseudolamella in males and by the expanded distal part of the scape in females. A revalidation of Fusciphantes Oi, 1960 and the establishment of Bifurcia Saaristo et al., 2006 are now recognized to be unsubstantiated because both were based on the symplesiomorphies. However, no nomenclatural changes are suggested due to the lack of type and comparative material for a detailed comparative analysis of these genera.

РЕЗЮМЕ. С Российского Дальнего Востока описан новый вид Arcuphantes maritimus sp.n., отличающийся от других видов рода формой парацимбиума и псевдоламеллы самца, а также строением дистального отдела эпигины самки. Ревалидизация Fusciphantes Oi, 1960 и установление рода Bifurcia Saaristo et al., 2006 признано необоснованным, как опирающиеся на симплезиоморфии, однако, за отсутствием типового и сравнительного материала необходимого для детального сравнения сходств и различий родов, никакие номенклатурные изменения не предложены.

\section{Introduction}

Although findings of new species of large-sized spiders become progressively improbable, such findings still take place. Twenty years ago, I found two males of large linyphiids in the Ussuri Pinus sibiricus taiga, which were impossible to assign reliably to any of the existing genera. Recently, an Arcuphantes-like female was found in the material collected from the locality lying some $200 \mathrm{~km}$ southward of that of the two aforementioned males; this female is most likely to be conspecific with those males.

While revalidating of Fusciphantes Oi, 1960, Saaristo et al. [2006] rejected its synonymy with Arcuphantes Chamberlin et Ivie, 1943 only on the basis of the insufficient figures by Oi [1960] rather than as a result of a reexamination of the type material. These authors justified their decision reasoning from: (1) that Arcuphantes had no tibial apophysis, whereas Fusciphantes had a very characteristically shaped proximal cymbial apophysis; (2) that Arcuphantes had the distinctly looking paracymbium; and (3) that the epigyne of Arcuphantes was straight, backward pointing, not the curled-like as in Fusciphantes.

Although no material on Fusciphantes has been available to me, the figures by Ihara [1995, 2007] and Ono et al. [2009] are indicative that $F$. longiscapus Oi, 1960 (the type species of Fusciphantes) does not possess the aforementioned tibial apophysis, whereas its epigyne is straight, as in Arcuphantes. Furthermore, according to the drawings by Chamberlin \& Ivie [1943], A. fragilis (the type species of Arcuphantes) actually has "a very characteristically shaped proximal cymbial apophysis" and the paracymbium of the same specific shape as that in Fusciphantes representatives. Thus, all the diagnostic characters given by Saaristo et al. [2006] for Arcuphantes in fact also present in Fusciphantes. Therefore, a revalidation of the latter genus should be considered ungrounded. Regretfully, the lack of access to type and comparative material on Arcuphantes and Fusciphantes has not allowed me to synonymize these genera again with confidence. Yet, a further re-examination of those material may provide evidences either that both genera are distinct, or that they are similar. 

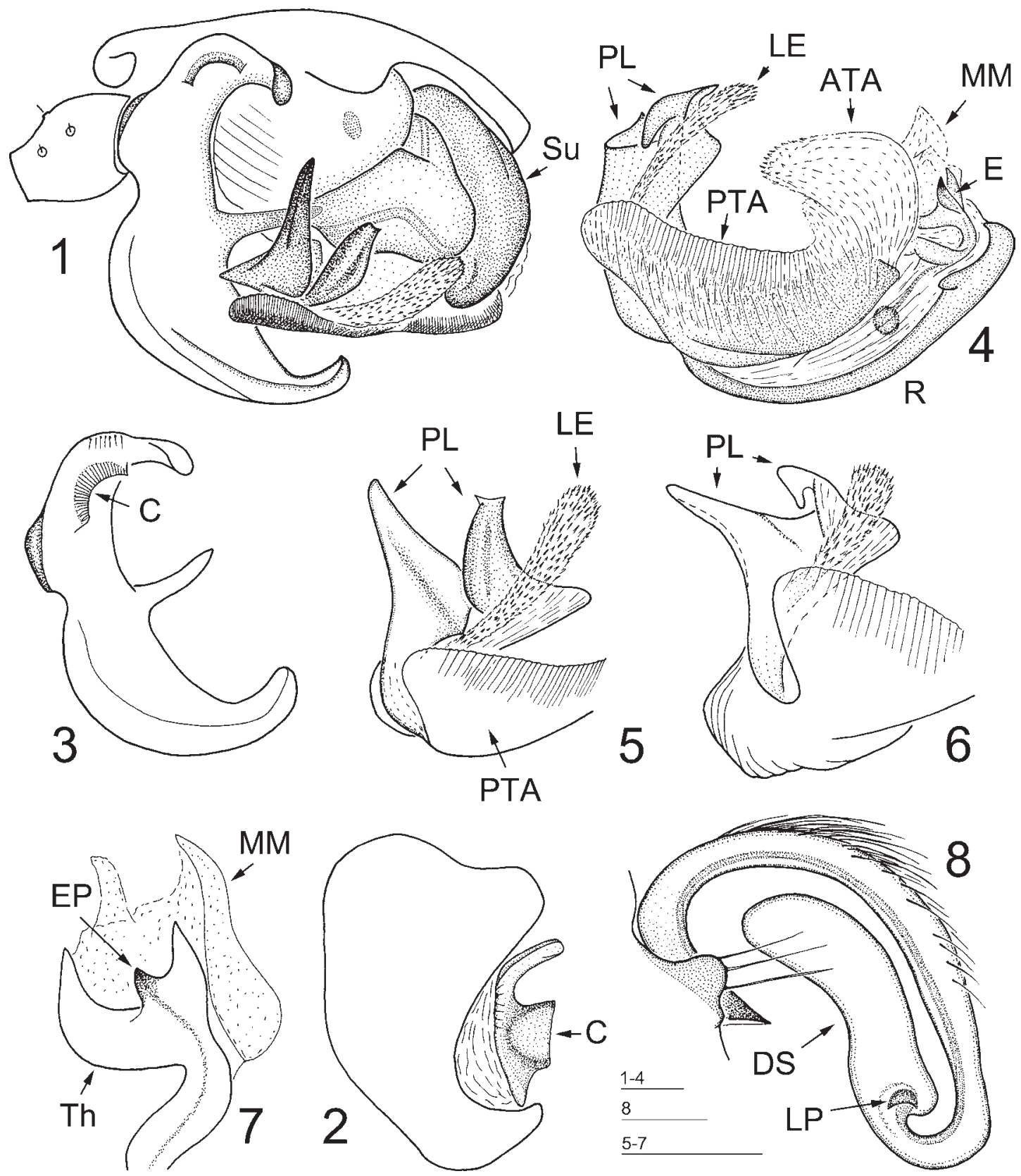

Figs 1-8. Arcuphantes maritimus sp.n., $0^{7} \&$ q paratypes: 1 - right palp; 2 - cymbium and paracymbium, dorsal view; 3 paracymbium; 4 - embolic division; 5, 6- posterior part of embolic division; 7 - embolus and median membrane; 8 - epigyne, lateral view. Abbreviations: ATA — anterior part of terminal apophysis; C — cirque-like formation on paracymbium; DS — distal part of scape; E - embolus; EP - embolus proper; LE - lamellar extension of pseudolamella; LP — lateral pocket; MM — median membrane; PL pseudolamella; PTA — posterior part of terminal apophysis; $\mathrm{R}$ — radix; $\mathrm{Su}$ — suprategulum; Th — thumb of embolus.

Рис. 1-8. Arcuphantes maritimus sp.n., O $_{\text {и }}+$ паратипы: 1 - правая пальпа; 2 - цимбиум и парацимбиум, вид сверху; 3 парацимбиум; 4 - эмболюсный отдел; 5,6 - задняя часть эмболюсного отдела; 7 - эмболюс и медиальная мембрана; 8 эпигина, вид сбоку.

While erecting of the new genus Bifurcia Saaristo, $\mathrm{Tu}$ et Li, 2006, Saaristo et al. [2006] indicated three characters distinguishing it from Arcuphantes/Fusciphantes, namely: (1) the apical part of the paracymbium is divided in two branches; (2) the relatively short, thick and stout tipped pseudolamella with a ribbon-like lamellar extension arising from its base; (3) the epigyne forms a more or less full circle. Incidentally, all of them can be found in the type species both of $A r$ cuphantes and of Fusciphantes, as well as in many other representatives of both genera. Indeed, the four currently known species of Bifurcia [Saaristo et al., 
2006; Zhai \& Zhu, 2007], as well as a new species described herein, comprise a homogenous group of very similar species. However, there is no reason to isolate this group as a separate genus because of the lack of any underlying synapomorphies.

From the above reasoning, the revalidation of Fusciphantes and erection of Bifurcia by Saaristo et al. [2006] seems to be completely groundless. Furthermore, both genera are likely to be junior synonyms of Arcuphantes, and this is why the oldest name $A r$ cuphantes is used here for the newly described species.

\section{Material and methods}

The present paper is based both on the spider material collected by the author in 1991 and on that collected by Daniil Osipov in 2008 from the southern part of the Maritime Province, Russia. The type material is deposited in the Zoological Museum of the Moscow State University, Moscow, Russia.

In the descriptions, chaetotaxy is given as follows: e.g., Ti I: 2-1-1-2, which means that the tibia I has two dorsal, one pro- and one retrolateral spine, and two ventral spines. The sequence of leg segment measurements is as follows: Femur + patella + tibia + metatarsus + tarsus. All measurements are given in $\mathrm{mm}$. Scale lines in the figures are $0.1 \mathrm{~mm}$.

The terminology of the genitalic structures follows Saaristo \& Tanasevitch [1996] and Saaristo et al. [2006]. Abbreviations used in the text and figures: ATA anterior part of terminal apophysis; $\mathrm{C}$ - cirque-like formation on paracymbium; DS - distal part of scape; E - embolus; EP — embolus proper; Fe - femur; LE - lamellar extension of pseudolamella; LP lateral pocket; $\mathrm{MM}$ - median membrane; $\mathrm{Mt}$ - metatarsus; PL — pseudolamella; PTA — posterior part of terminal apophysis; $\mathrm{R}$ - radix; $\mathrm{Su}$ - suprategulum; $\mathrm{Th}$ — thumb of embolus (= lateral extention); Ti tibia; TmI - position of trichobothrium on tibia I.

\section{Description}

\section{Arcuphantes maritimus sp.n.}

Figs $1-15$.

MATERIAL. Holotype $\sigma^{7}$, RUSSIA, Maritime Province, 35 $\mathrm{km}$ SE of Chyuguevka, Verkhneussuriyskiy Field Station (ca $\left.43^{\circ} 57^{\prime} \mathrm{N}, 134^{\circ} 01^{\prime} \mathrm{E}\right), 10 . \mathrm{VII} .1991$, leg. A. Tanasevitch. Paratypes: $1 \sigma^{7}$, same locality, together with holotype; 1 \%, Maritime Province, Kedrovaya Pad' Nature Reserve, Kedrovaya River, 0.5-1 km upstream of the reserve's central office, 8.X.2008, leg. D. Osipov.

DIAGNOSIS. The new species differs in having the peculiar shape of the paracymbium and the pseudolamella in the male and the expanded distal part of the scape in the female.

ETYMOLOGY. The species name is derived from the region where the new species was found; adjective.

DESCRIPTION. Male (paratype). Total length, 3.75. Carapace 1.70 long, 1.40 wide, unmodified, pale brown, with a narrow dark margin. Chelicerae 1.00 long, fang claw thick and abruptly bent. Legs pale brown, with no dark rings. Leg I, $10.55 \operatorname{long}(2.80+0.50+3.00+2.80+$ 1.45), IV - $9.45(2.75+0.45+2.50+2.60+1.15)$. Chaetotaxy. Fe I: 0-1-0-0, Fe II-IV: 0-0-0-0; Ti I-II: 2-11-2, III-IV: 2-1-1-0; Mt I-IV: 1-1-1-0. Metatarsus IV without trichobothrium. Tm I-0.18. Palp (Figs 1-7, 10, 11): Cymbium with a posterodorsal claw-shaped outgrowth. Paracymbium very large, with a cirque-like formation in its proximal part, and a spear-shaped process in its middle part. Suprategulum highly developed and sclerotized, pit hook reduced. Median membrane transformed into a small, formless, membraneous tissue. Anterior part of terminal apophysis transparent, posterior part as a flat wide ribbon. Fickert's gland small, spherical. Radical apophysis, named by Saaristo et al. [2006] as "pseudolamella", is divided into two lobes. Lamellar extention as a transparent, serrate, gradually widened stripe. Embolus very small, thumb well-developed. Abdomen 1.90 long, 1.10 wide, dorsal pattern as in Fig. 9.

Female. Total length, 3.25, habitus as shown in Fig. 12. Carapace 1.25 long, 1.00 wide, unmodified, greyish-brown. Chelicerae 0.60 long, unmodified. Legs greyish-brown, distal parts of segments darkened. Leg I, 8.05 long $(2.20+0.40+2.15+2.05+1.25)$, IV $7.05(2.10+0.35+1.80+1.85+0.95)$. Chaetotaxy as in the male. Tm I - 0.16. Abdomen 2.50 long, 1.65 wide, dorsally dark grey, with two rows of white spots, merging posteriorly. Epigyne (Figs 8, 13-15): Scape thin, long and coiled. Distal part of scape expanded, lateral lobes totally reduced. Posterior median plate wide, triangular.

TAXONOMIC REMARKS. The new species seems to be most similar to Bifurcia cucurbita Zhai et Zhu, 2007, known from Henan Province, China [Zhai \& Zhu, 2007], but differs from it by shape of the paracymbium and the pseudolamella in the male and by the expanded distal part of the scape in the female.

DISTRIBUTON. Southern part of the Maritime Province, Russia.

ACKNOWLEDGEMENTS. I am most grateful to Daniil Osipov who collected a female paratype of the new species. This study was supported in part by the Russian Foundation for Basic Research, Projects \# 09-04-01365-a, and \# 08-0492230-a.

\section{References}

Chamberlin R.V., Ivie W. 1943. New genera and species of North American linyphiid spiders // Bull. Univ. Utah. Vol.33. No.10. P.1-39.

Ihara Y. 1995.Taxonomic revision of the longiscapus-group of Arcuphantes (Araneae: Linyphiidae) in western Japan, with a note on the concurrent diversification of copulatory organs between males and females // Acta arachnol. Vol.44. P.129-152.

Ihara Y. 2007. Diversity in genital morphology and geographic differentiation patterns in the spider genera Cybaeus and $\mathrm{Ar}$ cuphantes (Araneae) in the Chugoku Mountains, Japan // Taxa, Proc. Japan. Soc. syst. Zool. Vol.22. P.20-30.

Ono H., Matsuda M., Saito H. 2009. Linyphiidae, Pimoidae // Ono H. (ed.). The Spiders of Japan with keys to the families and genera and illustrations of the species. Kanagawa: Tokai Univ. Press. P.253-344. 


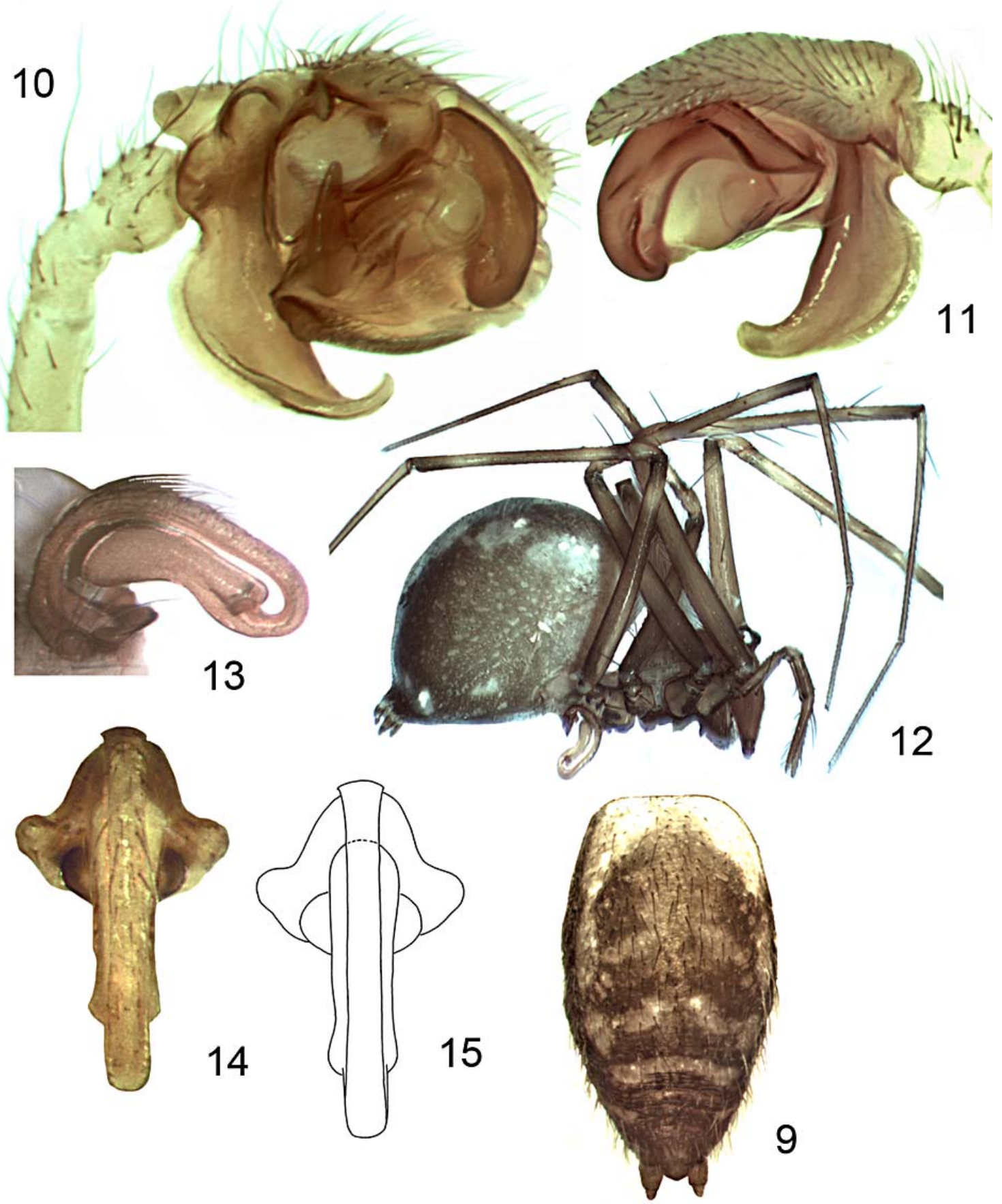

Figs 9-15. Arcuphantes maritimus sp.n. $\bigcirc^{7}$ holotype (9), O $^{7} \&$ paratypes (10-15): 9 - abdomen, dorsal view; 10, 11 - right palp, retro, and prolateral view, respectively (in 11 embolic division detached); 12 - habitus female, lateral view; 13-15 - epigyne, lateral (13) and ventral view $(14,15)$. Not to scale.

Pис. 9-15. Arcuphantes maritimus sp.n., О голотип (9), о и пальпа, ид спереди и сзади, соответственно (на рис. 11 эмболюсный отдел удален); 12 - самка, вид сбоку; $13-15$ - эпигина, вид сбоку (13) и снизу $(14,15)$. Не в масштабе.

Saaristo M.I., Tanasevitch A.V. 1996. Redelimitation of the subfamily Micronetinae Hull, 1920 and the genus Lepthyphantes Menge, 1866 with descriptions of some new genera // Ber. nat.-med. Verein Innsbruck. Bd.83. P.163-186.

Saaristo M.I., Tu L.H., Li S.Q. 2006. A review of Chinese micronetine species (Araneae: Linyphiidae). Part I: species of ex-
Arcuphantes and ex-Centromerus // Animal Biology. Vol.56. No.3. P.383-401.

Zhai H., Zhu M.S. 2007. Two new species of the genus Bifurcia (Araneae: Linyphiidae) from China // Acta arachnol. Vol.56. No.2. P.73-76. 